\title{
Reconstruction of crown length of Norway spruce (Picea abies (L.) Karst.) and Silver fir (Abies alba Mill.) - technique, establishment of sample methods and application in forest growth analysis
}

\author{
Peter SPATHELF \\ Forstdirektion Tübingen, Im Schloß, 72074 Tübingen, Germany
}

(Received 22 April 2002; accepted 27 November 2002)

\begin{abstract}
A technique to date branch mortality was used to estimate crown recession of Norway spruce and Silver fir in uneven-aged mixed forests on temporary plots of the Black Forest (Germany). In a preliminary study accurate and efficient sampling methods were developed. Results of the main study indicate that unthinned trees show a high crown recession rate, contrarily to thinned trees, which reveal more balanced crowns. Height increment and Hegyi's competition index were the only significant variables left in the final regression model. Trees of equal competition status but with higher height increment exhibit higher crown recession rates. This tendency is even more pronounced with Norway spruce than with Silver fir. Norway spruce, however, shows a higher crown recession rate with increasing competition compared with Silver fir of similar height increment. This seems to indicate a lower shade tolerance of Norway spruce.
\end{abstract}

Norway spruce / Silver fir / crown length / crown recession / branch mortality

Résumé - Évolution en hauteur des houppiers d'épicéa (Picea abies (L.) Karst.) et de sapin pectiné (Abies alba Mill.) - technique, mise en œuvre de méthodes d'échantillonnage, application à l'analyse de la croissance des forêts. On a utilisé une technique permettant de dater la mortalité des branches pour estimer la régression par le bas des houppiers de l'épicéa et du sapin pectiné, dans des placettes temporaires installées dans des forêts mélangées et inéquiennes de la Forêt Noire (Allemagne). Les résultats démontrent qu'en l'absence d'éclaircie les arbres présentent un taux de régression des houppiers plus élevé, au contraire des arbres ayant bénéficié d'éclaircies dont les houppiers apparaissent mieux équilibrés. L'accroissement en hauteur et l'indice de compétition de Hegyi sont les seules variables significatives qui subsistent dans le modèle de régression final. Les arbres soumis à un niveau de compétition équivalent, mais dont l'accroissement en hauteur est plus élevé, présentent un taux de régression du houppier plus important. Cette tendance est même plus prononcée pour l'épicéa que pour le sapin pectiné. Lorsque le niveau de compétition s'accroît, l'épicéa accuse un taux de réduction plus élevé que le sapin pectiné à accroissement en hauteur équivalent. Ceci semble indiquer une moindre tolérance à l'ombre de l'épicéa.

épicéa / sapin pectiné / hauteur de houppier / régression par le bas du houppier / mortalité des branches

\section{INTRODUCTION}

Crown size is a very important component of growth models (e.g. [2, 7, 12, 26, 27, 42]). The strong relationship between crown size and a tree's growth potential has been documented in many studies (e.g. [2, 4, 44]). Crown size has also be shown to reflect the competition a tree has experienced in the past ([24, 27, 40]).

Several studies have been dedicated to examine the relationship between crown parameters (e.g. crown transparency, crown ratio) and forest dieback in Central Europe ([19, 30, 32, 38]). An analysis of Silver fir in a forest of the Federal Swiss Research Station for Snow, Forest and Landscape near Zürich showed the significant influence of crown length on tree vitality [33].
Today, crown length is included in the parameter list in most of the forest inventories (e.g. [8]). Crown length is also used in models to predict the value of trees [5], as well as an independent variable in volume equations (e.g. Douglas fir in the Northeast of the US, [13]). In addition, crown length has been shown to be an estimator of thinning response [16]. Thinning slows down crown recession and thus leads to longer crowns than in unthinned stands (e.g. [20]).

Research has shown that for conifers crown length is a good indicator for growth potential and vitality. Based on stem analysis of Silver fir, Gerecke [11] found that trees with longer crowns (crown ratio $>35 \%$ ) showed a better diameter growth than trees with shorter crowns (crown ratio $<35 \%$ ). Spiecker [39] found a nearly linear relationship between crown ratio and diameter

\footnotetext{
* Corresponding author: Peter.Spathelf@ forst.bwl.de
} 
increment of Norway spruce and Silver fir in selection forests of the Black Forest. He recommended crown ratio as a sound criteria for estimating growth potential and vitality of trees in selection forests. Pretzsch [27] emphasised that crown length is an important parameter which is related to a tree's diameter growth and length of the clear bole.

Nevertheless, our knowledge on crown length estimation is restricted to a few studies only, especially for the US (e.g. [21]). Many studies exist on height growth estimation of the main conifer species, but little has been done to model the development of height to crown base. According to Short and Burkhart [35] this is related to the (1) lack of data and the (2) difficulties of defining crown base due to crown asymmetry. Provided that appropriate data are available, crown parameters can be incorporated as independent variables in growth models and thus improve their estimation accuracy.

Crown development has been modelled from cross-sectional and longitudinal data. Most of the crown models established predict crown size at the end of each observation period from the updated predictor variables (see review by Maguire and Hann [21]). A new approach conducted by Maguire and Hann [21], using a technique to date branch mortality, allows the direct estimation of 5-year crown recession across a wide range of site and stand conditions.

The present study [37] aims to establish a model for predicting crown recession of Norway spruce and Silver fir from temporary plots of the Black Forest using the dating technique described in Maguire and Hann [21]. In order to select an appropriate, i.e. accurate and efficient sampling method to determine crown recession, a preliminary study with five trees was conducted.

\section{MATERIALS AND METHODS}

\subsection{Physiography, climate, soils and stand structure}

The nine temporary sample plots are located in the Black Forest, one of the seven basic physiographic units of the site classification system of the federal state of Baden-Württemberg, in Southwest Germany. The altitude of the Black Forest ranges from 300 to $1500 \mathrm{~m}$ asl. The climate is oceanic temperate with high annual precipitation and relatively warm winters. Mean average temperatures range from 5 to $7{ }^{\circ} \mathrm{C}$. Precipitation averages 1000 to $1500 \mathrm{~mm}$ with a strong altitudinal gradient and is mainly distributed in winter. Bedrock of the area consists of a mixture of granite, gneiss and sandstone formations. The predominant soils are brown soils of medium fertility, sometimes with podzolic layers which are due to acidification processes.

The stand structure in the study area is characterised by mixed uneven-aged stands with groups of naturally regenerated Norway spruce and Silver fir. This type of heterogeneous uneven-aged conifer stands in private ownership is typical for the natural range of Silver fir in higher elevations of the Black Forest (Southwest Germany). A special management form of these forests is the so-called selection forest ("Plenterwald") with a negative "J-shaped" size (and age) class distribution on very small areas [25].

\subsection{Selection of stands and sample trees}

The samples were taken in mixed uneven-aged parts of stands of Norway spruce and Silver fir with natural regeneration (mostly for- ests in transformation from even-aged forests into mixed unevenaged forests). In the sampled stands interventions of different degrees have been conducted in order to (1) harvest single trees or tree groups, (2) to thin, or (3) to improve conditions for natural regeneration.

In every selected stand trees with different degrees of thinning (competition status) were randomly sampled. As crown size reflects the competition a tree has experienced in the past, the selected trees covered a wide range of crown lengths (Tab. I). The sampled trees were from different sociological positions, including codominant and dominated trees. All sample trees were felled and stem analysis was conducted. Furthermore, an analysis of branch whorls was conducted in order to define the date of branch mortality.

The stump of the sample tree was seen as the centre of a Bitterlich sample. Based on a basal area factor of 4 all neighbouring trees within the relascope sample were measured in order to express competition of the central (sample) tree. Competition was calculated using Hegyi's index [15] which is defined as the ratio between diameter at breast height of the neighbouring trees and that of the central tree multiplied with the inverse horizontal distance between the central and neighbouring trees (Eq. (1)).

$$
\sum_{j=1}^{n} \frac{d b h_{j}}{d b h_{i}\left(d i s t_{i j}+1\right)}
$$

$d b h$ : diameter at breast height $[\mathrm{cm}] ;$ dist: horizontal distance between the central tree and its neighbours [m]; $i$ : sample tree; $j$ : neighbour trees.

Crown ratio was calculated in accordance with equation (2).

$$
c r=c l / h \times 100
$$

cr: crown ratio [\%]; $c l$ : crown length [m]; $h$ : tree height [m].

Current crown ratio was measured at the felled sample trees. The criteria used to define height to crown base is the last green whorl with at the most one dead branch from the top of the tree.

\subsection{Tree characteristics}

Table I shows some characteristics of the sample trees. Altogether 57 spruces and 43 firs from nine sample plots were measured. The sample encompasses trees of different growth histories. Mean height of the trees ranges from 25.2 to $34.3 \mathrm{~m}$, mean diameter at breast height from 29.0 to $45.6 \mathrm{~cm}$. The five trees for the preliminary study were sampled in stand 1 (Wolfach).

\subsection{Branch characteristics}

The main characteristics of the analysed branch whorls are shown in Table II. Altogether 84 fir and 100 spruce whorls were sampled on the nine temporary plots. The mean number of branches per whorl was 2 to 3 with the exception of plot 5 (species: Silver fir) with only one branch per whorl. The life span of the branches varies between 19.0 and 44.8 years for Silver fir and between 21.3 and 44.8 years for Norway spruce. Mean crown base recession per year was measured for two sampling methods (for sampling strategies and the technique to obtain the date of branch death see Tab. III and Sect. methods).

\subsection{Design of branch whorl analysis}

A precise reconstruction of a tree's crown length requires the examination of each whorl in the dead branch zone of the tree. This is a time consuming and cost intensive work and therefore not feasible for a large number of trees. In order to establish a sampling design for whorl analysis a subsample of five trees (stand 1, see Tab. I) was analysed in a feasibility study. 


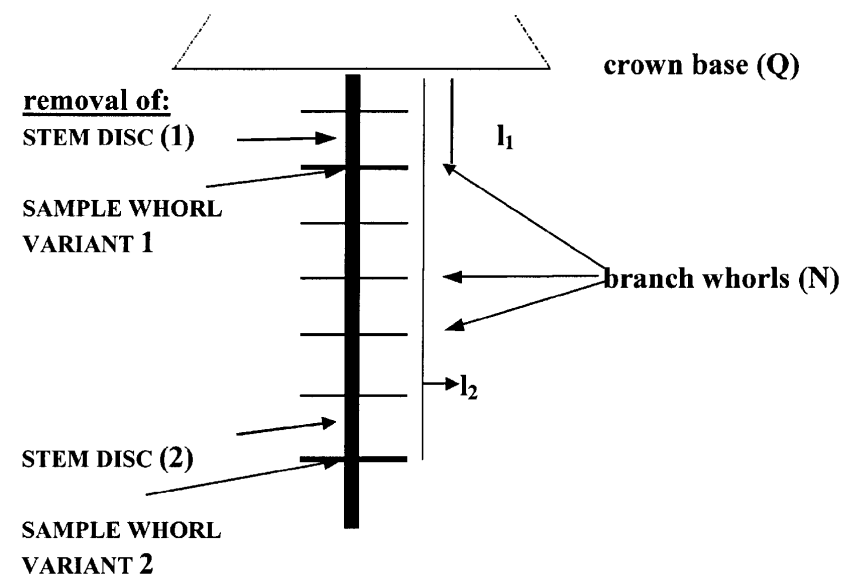

$$
C b h=\frac{l_{n}}{t}
$$

\begin{tabular}{|c|c|}
\hline Cbh: & Change of height to crown base $[\mathrm{cm} / \mathrm{a}]$ \\
\hline$l_{n}:$ & $\begin{array}{l}\text { Distance between the studied whorl and the current height to } \\
\text { crown base [cm] }\end{array}$ \\
\hline$t$ & $\begin{array}{l}\text { Time between the loss of status of height to crown base and tree } \\
\text { sampling [a] }\end{array}$ \\
\hline
\end{tabular}

Figure 1. Schematic demonstration of the experimental design to analyse crown recession (localisation of discs and whorls and calculation procedure).

Table I. Mean tree characteristics with the respective standard error (in italics) of the sampled Norway spruces and Silver firs.

\begin{tabular}{|c|c|c|c|c|c|c|c|}
\hline $\begin{array}{l}\text { Stand } \\
(n, \text { trees })\end{array}$ & Species sampled & Height & $\begin{array}{c}\text { Diameter at } \\
\text { breast height }\end{array}$ & $\begin{array}{l}\text { Crown } \\
\text { ratio }\end{array}$ & $\begin{array}{l}\text { Height to crown } \\
\text { base }\end{array}$ & Crown length & $\begin{array}{c}\text { Radial } \\
\text { increment* }\end{array}$ \\
\hline & & {$[\mathrm{m}]$} & {$[\mathrm{cm}]$} & {$[\%]$} & {$[\mathrm{m}]$} & {$[\mathrm{m}]$} & {$[\mathrm{mm} / \mathrm{a}]$} \\
\hline $\begin{array}{l}1 \text { Wolfach } \\
\text { (9) }\end{array}$ & Silver fir & $\begin{array}{l}26.6 \\
1.77\end{array}$ & $\begin{array}{l}34.0 \\
5.45\end{array}$ & $\begin{array}{c}47 \\
8.90\end{array}$ & $\begin{array}{l}14.1 \\
2.42\end{array}$ & $\begin{array}{l}12.6 \\
2.63\end{array}$ & $\begin{array}{l}6.30 \\
1.98\end{array}$ \\
\hline $\begin{array}{l}2 \text { Todtmoos } \\
\text { (16) }\end{array}$ & Silver fir & $\begin{array}{l}26.8 \\
2.89\end{array}$ & $\begin{array}{l}39.7 \\
6.08\end{array}$ & $\begin{array}{c}18 \\
6.37\end{array}$ & $\begin{array}{l}21.9 \\
2.53\end{array}$ & $\begin{array}{l}4.94 \\
1.92\end{array}$ & $\begin{array}{l}2.95 \\
1.46\end{array}$ \\
\hline $\begin{array}{l}3 \text { St. Blasien } \\
\text { (6) }\end{array}$ & Norway spruce & $\begin{array}{l}29.8 \\
1.31\end{array}$ & $\begin{array}{l}44.2 \\
9.04\end{array}$ & $\begin{array}{c}36 \\
8.13\end{array}$ & $\begin{array}{l}19.1 \\
1.96\end{array}$ & $\begin{array}{l}10.7 \\
2.69\end{array}$ & $\begin{array}{l}4.31 \\
2.45\end{array}$ \\
\hline $\begin{array}{l}4 \text { St. Blasien } \\
\text { (9) }\end{array}$ & Silver fir & $\begin{array}{l}26.0 \\
1.69\end{array}$ & $\begin{array}{l}38.0 \\
3.61\end{array}$ & $\begin{array}{c}24 \\
5.39\end{array}$ & $\begin{array}{l}19.8 \\
0.97\end{array}$ & $\begin{array}{l}6.27 \\
1.77\end{array}$ & $\begin{array}{l}4.53 \\
1.71\end{array}$ \\
\hline $\begin{array}{l}5 \text { Freudenstadt } \\
\text { (9) }\end{array}$ & Silver fir & $\begin{array}{l}28.7 \\
2.71\end{array}$ & $\begin{array}{l}45.6 \\
6.22\end{array}$ & $\begin{array}{c}27 \\
5.76\end{array}$ & $\begin{array}{l}20.8 \\
2.44\end{array}$ & $\begin{array}{l}7.87 \\
1.79\end{array}$ & $\begin{array}{l}3.79 \\
2.35\end{array}$ \\
\hline $\begin{array}{l}6 \text { Altensteig } \\
\text { (16) }\end{array}$ & Norway spruce & $\begin{array}{l}34.3 \\
3.40\end{array}$ & $\begin{array}{l}42.9 \\
5.61\end{array}$ & $\begin{array}{c}39 \\
5.68\end{array}$ & $\begin{array}{l}20.8 \\
2.58\end{array}$ & $\begin{array}{l}13.5 \\
2.52\end{array}$ & $\begin{array}{l}5.38 \\
1.92\end{array}$ \\
\hline $\begin{array}{l}7 \text { Pfalzgrafen-weiler } \\
\text { (15) }\end{array}$ & Norway spruce & $\begin{array}{l}26.2 \\
2.24\end{array}$ & $\begin{array}{l}29.0 \\
3.76\end{array}$ & $\begin{array}{c}33 \\
5.13\end{array}$ & $\begin{array}{l}17.5 \\
2.24\end{array}$ & $\begin{array}{l}8.72 \\
1.34\end{array}$ & $\begin{array}{l}3.73 \\
1.13\end{array}$ \\
\hline $\begin{array}{l}8 \text { Oppenau } \\
\text { (10) }\end{array}$ & Norway spruce & $\begin{array}{l}25.2 \\
4.41\end{array}$ & $\begin{array}{l}35.1 \\
8.16\end{array}$ & $\begin{array}{c}46 \\
10.55\end{array}$ & $\begin{array}{l}13.9 \\
4.11\end{array}$ & $\begin{array}{l}11.3 \\
2.44\end{array}$ & $\begin{array}{l}4.56 \\
2.14\end{array}$ \\
\hline $\begin{array}{l}9 \text { Villingen } \\
\text { (10) }\end{array}$ & Norway spruce & $\begin{array}{l}29.4 \\
1.98\end{array}$ & $\begin{array}{l}37.8 \\
4.91\end{array}$ & $\begin{array}{c}35 \\
6.19\end{array}$ & $\begin{array}{l}19.1 \\
1.98\end{array}$ & $\begin{array}{l}10.3 \\
2.11\end{array}$ & $\begin{array}{l}3.20 \\
0.84\end{array}$ \\
\hline
\end{tabular}

* Mean radial increment at breast height $(1.3 \mathrm{~m})$ during the last 10 years before sampling.

Two methods with individual whorl sampling (variant 1 and 2) were compared with the mean recession rate of all whorls withdrawn from the bole (variant 3) and an interpolation method (variant 4) (Tab. III). First, the next whorl to each cross-sectional disc taken for classical stem analysis (every five $\mathrm{m}$, beginning at breast height) was removed within the dead branch zone, i.e. the zone below height to crown base (variant 1 and 2). Then a further whorl was removed in every $2 \mathrm{~m}$-section within the dead branch zone, beginning from height to crown base. In general, two whorls per tree were analysed. In Figure 1 the procedure of whorl analysis is outlined. Recession rate 
Table II. Mean branch characteristics and their respective standard error (in italics).

\begin{tabular}{|c|c|c|c|c|c|}
\hline Stand & $1^{*}$ & $\begin{array}{c}n \\
\text { whorls }\end{array}$ & $\begin{array}{l}\text { Mean number } \\
\text { of branches per } \\
\text { whorl }\end{array}$ & $\begin{array}{l}\text { Crown base } \\
\text { recession } \\
\text { variant } 1\end{array}$ & $\begin{array}{c}\text { Crown base } \\
\text { recession } \\
\text { variant } 2\end{array}$ \\
\hline & & & [n] & {$[\mathrm{cm} / \mathrm{a}]$} & {$[\mathrm{cm} / \mathrm{a}]$} \\
\hline 1 & 1 & 7 & 3 & $\begin{array}{l}56.8 \\
1.06\end{array}$ & - \\
\hline 1 & 2 & 9 & 3 & - & $\begin{array}{l}40.6 \\
1.28\end{array}$ \\
\hline 2 & 1 & 16 & 3 & $\begin{array}{l}19.8 \\
0.21\end{array}$ & - \\
\hline 2 & 2 & 16 & 3 & - & $\begin{array}{l}15.6 \\
0.25\end{array}$ \\
\hline 3 & 1 & 9 & 3 & $\begin{array}{l}28.0 \\
0.23\end{array}$ & - \\
\hline 3 & 2 & 9 & 2 & - & $\begin{array}{l}18.6 \\
0.41\end{array}$ \\
\hline 5 & 1 & 9 & 3 & $\begin{array}{l}29.4 \\
0.38\end{array}$ & - \\
\hline 5 & 2 & 9 & 1 & - & $\begin{array}{l}16.2 \\
0.30\end{array}$ \\
\hline 4 & 1 & 6 & 2 & $\begin{array}{l}21.2 \\
0.86\end{array}$ & - \\
\hline 4 & 2 & 6 & 2 & - & $\begin{array}{l}14.2 \\
0.52\end{array}$ \\
\hline 6 & 1 & 8 & 2 & $\begin{array}{l}32.2 \\
0.83\end{array}$ & - \\
\hline 6 & 2 & 16 & 2 & - & $\begin{array}{l}19.8 \\
0.78\end{array}$ \\
\hline 7 & 1 & 14 & 3 & $\begin{array}{l}45.8 \\
0.60\end{array}$ & - \\
\hline 7 & 2 & 15 & 2 & - & $\begin{array}{l}38.2 \\
0.95\end{array}$ \\
\hline 8 & 1 & 6 & 2 & $\begin{array}{l}32.8 \\
1.00\end{array}$ & - \\
\hline 8 & 2 & 10 & 2 & - & $\begin{array}{l}25.6 \\
1.22\end{array}$ \\
\hline 9 & 1 & 9 & 3 & $\begin{array}{l}19.2 \\
0.24\end{array}$ & - \\
\hline 9 & 2 & 10 & 3 & - & $\begin{array}{l}24.8 \\
1.06\end{array}$ \\
\hline
\end{tabular}

Note: Silver fir whorls are in the upper part (stands 1-3 and 5), Norway spruce whorls in the lower part (stands 4 and 6-9) of the table. *1: Localisation of whorl samples (see Sect. methods).

is defined as the relationship of the distance between the studied whorl and the current height to crown base and the time between the loss of status of height to crown base and tree sampling.

To date branch mortality the removed whorls were treated as follows (see Fig. 2).

First all the sampled whorls were ripped up by a band saw with a precise radial cut.

Twenty percent of the whorls were also cut cross-sectionally through the dead branches of the respective whorls. Then the whorl surfaces were polished with emery paper. Branch mortality was dated

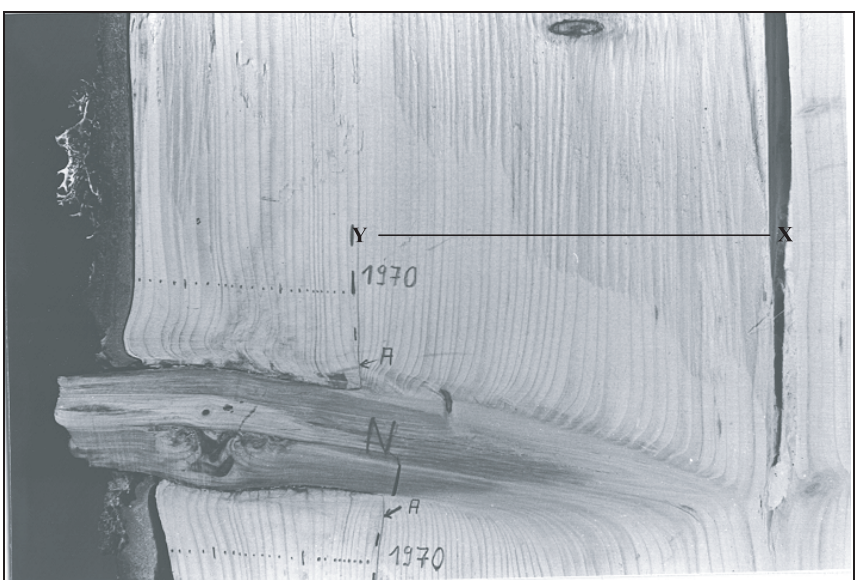

Figure 2. Radial section through a Silver fir whorl.

by finding those tree rings where a discontinuity between the branch rings and those of the trunk could be observed. The respective date of that tree ring was seen to be the date of branch mortality.

In the example (Fig. 2), the date of branch mortality (A) was determined to be the year 1970 (24 years back from felling). Before 1970 the annual tree rings of the trunk have connection with branch rings, contrarily to the period between 1970 and the date of tree felling (for more criteria to determine the date of branch mortality see the text below). The date of branch mortality is the same above and below branch insertion. $\mathrm{N}$ (= north) shows the direction of the branch, whereas the distance between $\mathrm{X}$ and $\mathrm{Y}$ corresponds to the life span of the branch.

This dating technique described by Rapraeger [28], Maguire and Hann [21] and Fujimori [9] allows the dating of branch mortality with an accuracy of one or two years. As a branch can die in the beginning, middle or the end of a year, half a year was systematically added to the date of branch mortality. Further criteria relating to wood anatomy were used to determine the year of branch mortality (e.g. [9, 21]):

(1) In some cases resin deposits (barrier zone) can be observed in the adjacent tree ring to the ring of branch mortality. This barrier zone corresponds to the compartmentalisation zone of Shigo [34].

(2) Within the outer tree rings of the dead part of the branch a coloration indicates the beginning of wood decay (Fig. 2).

(3) Those tree rings which do not have any connection with branch wood show a particular wavy form shortly before they strike the branch wood.

The following assumptions were made for calculating the degree of crown recession:

(1) The dieback process of a branch is occurring within one year.

(2) A whorl looses its status as crown base if two or more branches in a whorl are dead.

(3) The year when a whorl looses its status as crown base is determined by the mean of the single branch mortality dates.

\section{RESULTS}

\subsection{Proposal of sampling method for dating crown recession}

The results of the different variants are presented in Figures 3-6. Figures 5 and 3 are referring to variant 1 and 2 compared with the individual values of height to crown base obtained by the branch mortality dating technique. Figure 4 


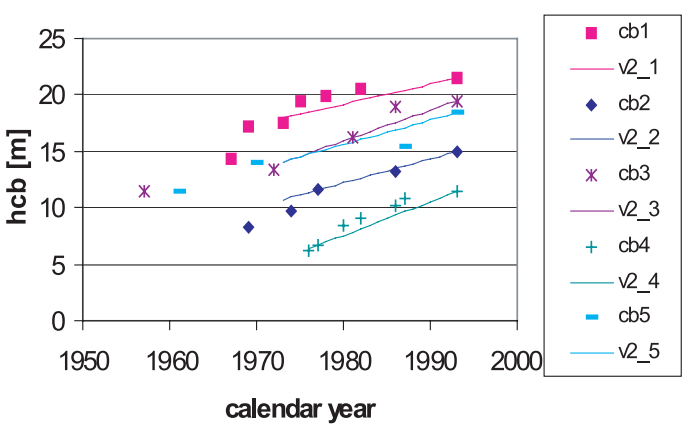

3

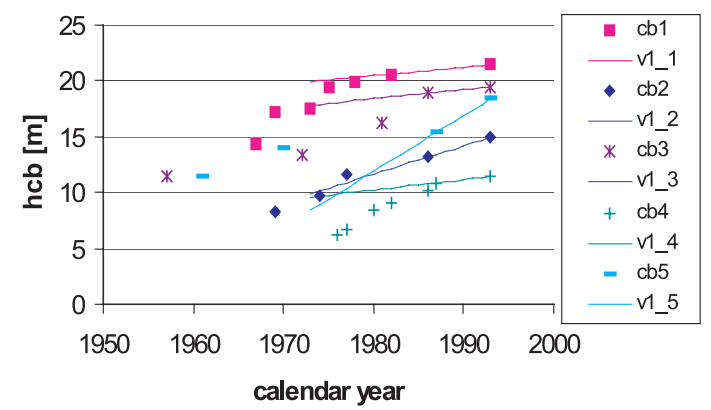

5

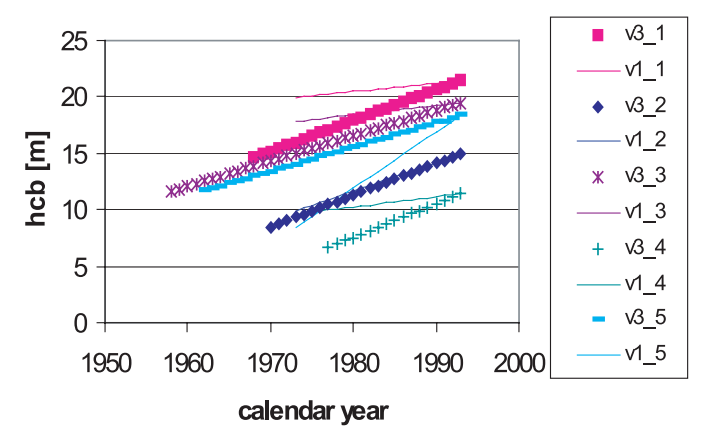

4

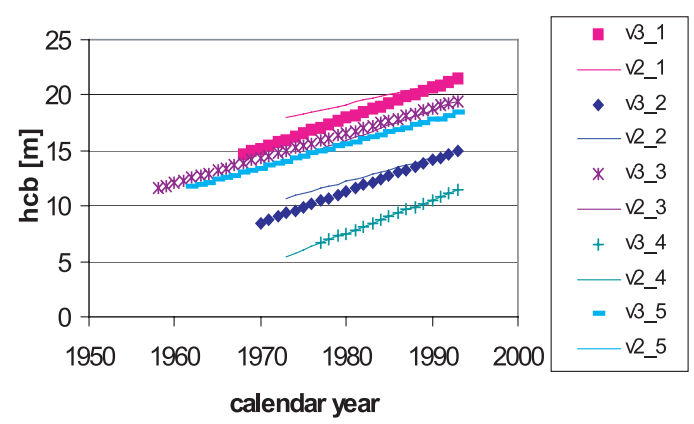

6

Figures 3-6. Comparison of crown recession (change of hcb = height to crown base) of the five sample trees with different variants (see Tab. III) (5: variant 1 against individual values of height to crown base; 3: variant 2 against individual values of height to crown base; 4: variant 3 against variant 1; 6: variant 3 against variant 2; where v1_1 means estimation of height to crown base (tree 1) with variant 1, v2_1 estimation of height to crown base (tree 1 ) with variant 2 etc. and cb1 individual values of height to crown base of tree 1 obtained by the branch mortality dating technique, $\mathrm{cb} 2$ of tree 2 , etc.).

Table III. Comparison of the methods for establishing a design of whorl analysis.

\begin{tabular}{l}
\begin{tabular}{l} 
Variant \\
\hline 1 \\
2 \\
Determination of crown recession considering the second whorl in the dead branch zone below height to crown base \\
next to a withdrawn stem disc \\
4 \\
Calculation of mean crown recession rate considering all the whorls withdrawn
\end{tabular} \\
\hline
\end{tabular}

shows the results of variant 1 against the mean values of all whorls analysed (variant 3) and Figure 6 compares variant 3 with the interpolation method (variant 4).

Variant 1 gives a good estimate of current crown recession figures (Fig. 5), whereas variant 2 is closer to the crown recession development of the last 20 years back from sampling (Fig. 3). The mean values of all whorls show a good correspondence with variant 2 but differ clearly from variant 1 (Fig. 4), i.e. variant 3 more reflects the crown recession of the past 20 years. The interpolation method also corresponds well with the mean values (Fig. 6). Due to their lower sampling intensity, variant 1 and 2 are less labour and therefore costintensive than variant 3 and 4.

In Table IV the mean percentile deviation of height to crown base and crown length of the sample trees measured with var- iant 1 and 2 from variant 4 (interpolation method) is shown for $5,10,15$ and 20 years back from sampling date. The height to crown base and crown length can be estimated with an error of at the most $5 \%$ compared with the interpolation method.

In Figure 7 the development of the height to crown base of the five sample trees is shown. For the estimation of crown recession the interpolated individual values of height to crown base (variant 4) were used. With the exception of sample tree 1 all trees show a decline in crown ratio. The greatest loss in crown ratio is shown by tree 2 from values of $60 \%$ to approximately $40 \%$ at the time of felling.

The preliminary study (Figs. 3-7 and Tab. IV) shows the feasibility of (1) sampling variant 1 in order to estimate current crown recession, (2) sampling variant 2 for restoring crown length development during the last 20 years. 
Table IV. Mean percentile deviation of height to crown base and crown length of the five sample trees measured with variant 1 and 2 compared with variant 4 (interpolation method).

\begin{tabular}{|c|c|c|c|c|}
\hline \multirow{2}{*}{ Calendar year } & \multicolumn{2}{|c|}{ Sampling variant 1} & \multicolumn{2}{|c|}{ Sampling variant 2} \\
\hline & Height to crown base & Crown length & Height to crown base & Crown length \\
\hline & \multicolumn{2}{|c|}{$[\%]$} & \multicolumn{2}{|c|}{$[\%]$} \\
\hline 1993 & 1 & 0 & 1 & 0 \\
\hline 1988 & 1 & 0 & 2 & 1 \\
\hline 1983 & 1 & 1 & 2 & 3 \\
\hline 1978 & 5 & 2 & 1 & 2 \\
\hline 1973 & 1 & 4 & 4 & 5 \\
\hline
\end{tabular}

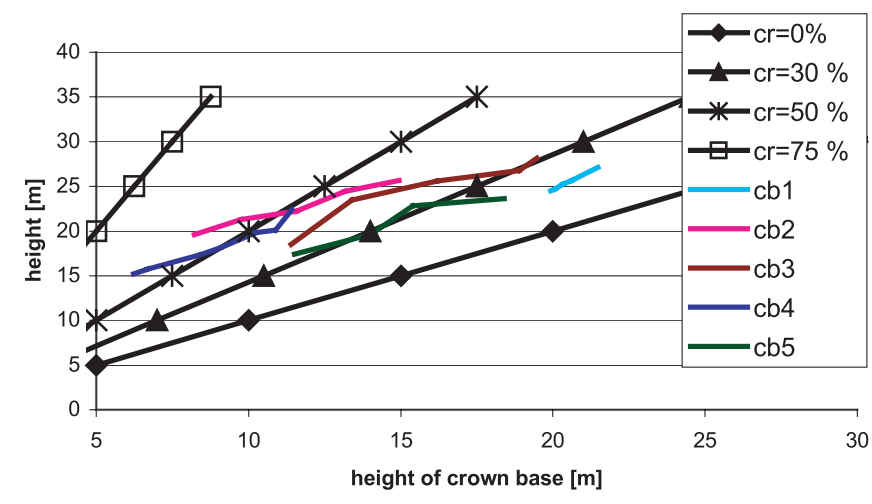

Figure 7. Comparison of crown ratio of the five sample trees (cr: crown ratio; cb1...: interpolated individual values of height to crown base).

\subsection{Relationship between height and height to crown base}

In Figure 8 the development of height to crown base against height of four sample trees with a different degree of release is shown. The individual values of branch mortality of the respective whorls were used for the estimation of the height to crown base (see Sect. methods). The Silver fir trees originate from stand 2 and suffered severe competition. The Norway spruce trees (stand 7) were thinned in the year of 1985. Unthinned trees show a high crown recession rate, i.e. the upwards shift of the height to crown base is faster than height growth. Thinned trees on the other hand do not reveal accelerated crown recession, thus showing a more balanced crown development.

\subsection{Comparison of crown ratio over time of thinned and unthinned trees}

The development of crown ratio over time of all thinned trees is compared with the unthinned trees. The results for the 57 Norway spruces and 43 Silver firs is shown in Figure 9. Estimation of crown recession was done by using variant 1 (see Tab. III). All trees with the exception of thinned Silver fir can be characterised by a declining crown ratio with time. But
Table V. Statistics of the relationship between height increment and change of the height to crown base (Y) and the competition status (CI) using Hegyi's index.

\begin{tabular}{|c|c|c|c|c|c|}
\hline Model & $\begin{array}{l}\text { Parameter } \\
\text { estimate }\end{array}$ & Prob $>F$ & $\begin{array}{c}\text { Species } \\
\text { (number of } \\
\text { observations) }\end{array}$ & MSE & $\mathrm{R}^{2}$ \\
\hline \multirow[t]{2}{*}{$\mathrm{Y}=\mathrm{a}_{0}+\mathrm{a}_{1} \mathrm{CI}$} & $\begin{array}{l}\mathrm{a}_{0}=3.736017 \\
\mathrm{a}_{1}=-1.060171\end{array}$ & 0.0129 & $\begin{array}{l}\text { Norway spruce } \\
\quad(n=57)\end{array}$ & 0.68 & 0.11 \\
\hline & $\begin{array}{l}\mathrm{a}_{0}=2.110726 \\
\mathrm{a}_{1}=-0.531407\end{array}$ & 0.0564 & $\begin{array}{c}\text { Silver fir } \\
(n=43)\end{array}$ & 0.77 & 0.09 \\
\hline
\end{tabular}

nevertheless, trees which were not thinned show higher crown recession rates (i.e. crown ratio is declining faster) than those which were thinned, Norway spruce, as well as Silver fir. For example unthinned Silver fir looses about $20 \%$ of its original crown ratio (year 0, see Fig. 9) in 10 years in comparison to unthinned Norway spruce which looses approximately $14 \%$. However, thinned Silver fir was able to take advantage of the increasing growing space and nearly sustains its crown dimension (here crown ratio). In both groups crown ratio of Norway spruce was remarkably larger than crown ratio of Silver fir.

\subsection{Crown recession, height growth and competition}

Within the possible factors which influence crown recession rate (height and diameter growth, competition, natural pruning behaviour of the species) height increment and the competition status of a tree seem to play a key role ([21], see also Fig. 9).

Linear regression analysis shows a significant influence of competition on the ratio of height increment and change of the height to crown base. Unfortunately the relationship is not very strong (Tab. V). The graph shows the competition which may not be exceeded if a determined crown ratio is intended to be maintained (Fig. 10). The increase of competition leads to a decreasing $\mathrm{ih} / \mathrm{chb}$ ratio for both species.

In the case of increasing competition, crown recession accelerates and with the height increment being equal the crown ratio decreases.

The magnitude of the relationship between height increment and change of height to crown base (crown recession 

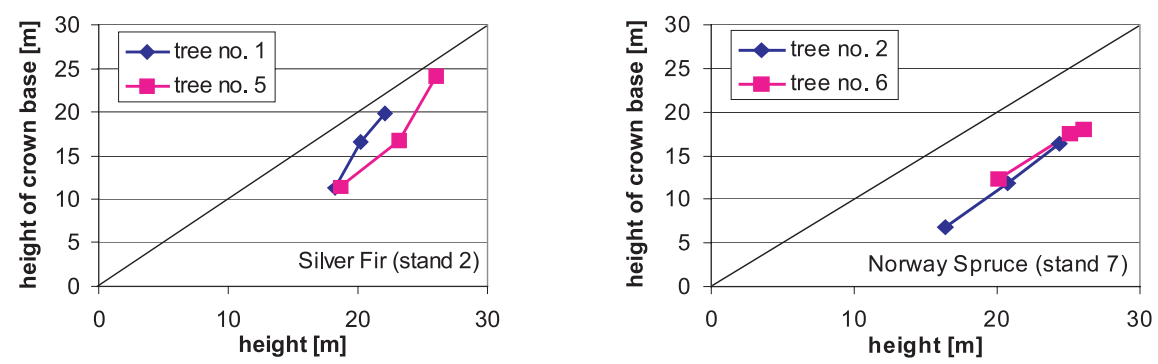

Figure 8. Development of the height to crown base over height of four sample trees (left: Silver fir, suffering severe competition, right: Norway spruce, released; diagonal = crown length 0 ).
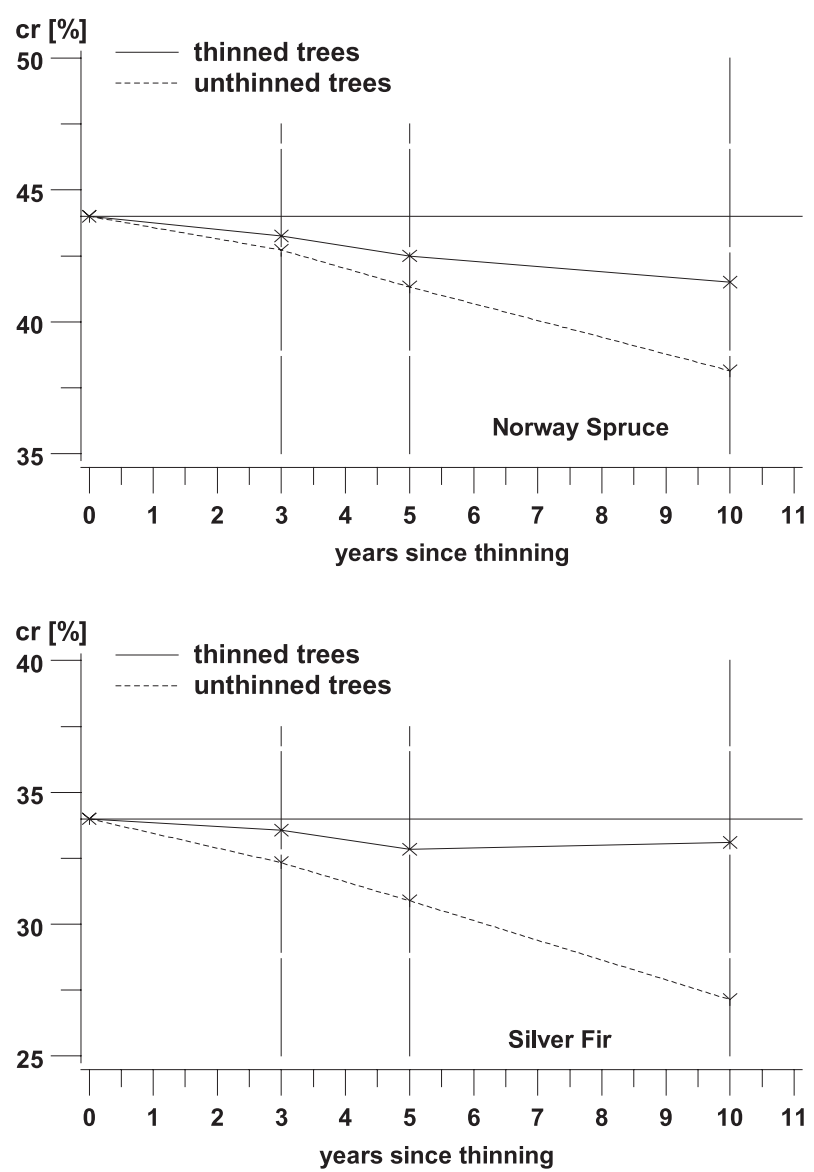

Figure 9. Development of crown ratio (cr) of thinned and unthinned Norway spruce and Silver fir up to 10 years since thinning. With the exception of thinned Silver fir all trees are declining in crown ratio, the unthinned trees more than the thinned ones.

rate) can be seen as an indicator of the competition a tree has experienced. If crown recession rate is lower than height increment, crown length is increasing and vice versa.

\subsection{Final model of crown recession}

The final model to estimate crown recession rate was established using multiple regression analysis (procedure "stepwise"). As independent variables diameter and age at breast height and diverse transformations of diameter, age, height

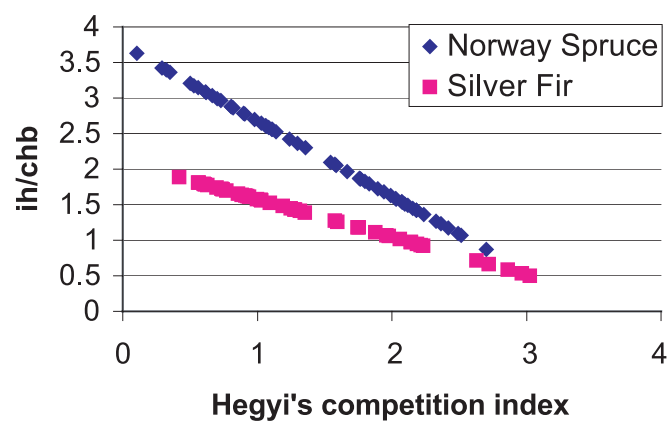

Figure 10. Relationship between height increment and change of the height to crown base (ih/chb) in function of the competition status based on Hegyi's index.

increment and competition were tested. Height increment and Hegyi's competition index were the only significant independent variables left in the model (significance level for model entry was 0.15 ).

In Table VI parameter estimates and the adjusted coefficient of determination ( $\left.\mathrm{R}^{2} \mathrm{adj}\right)$ are shown. The relationship between the independent variables and the response variable is also visualised by a three-dimensional response surface (Fig. 11).

With increasing competition crown recession is increasing too. Trees of equal competition status but with higher height increment, which means more vigorous trees, exhibit higher crown recession rates. In the case of two identically competed trees this tendency is more pronounced with Norway spruce than with Silver fir. On the other hand, Norway spruce shows a higher crown recession rate with increasing competition compared with Silver fir of similar height increment. This seems to indicate a lower shade tolerance of Norway spruce as a consequence of a reduced photosynthetic efficiency.

\section{DISCUSSION}

In the present study a branch dating technique was used to reconstruct the height to crown base of Norway spruce and Silver fir. The reasons why crown length reconstruction with destructive techniques in the past decades has received increased interest are: (1) the lack of crown height measurements on permanent observation plots, (2) the difficulty to determine the height to crown base, e.g. with asymmetric crowns on standing trees. 
Table VI. Statistics for the final model of crown recession rate (Y, calculated by using variant 1), depending from height increment (ih) and competition status (CI).

\begin{tabular}{|c|c|c|c|c|c|}
\hline Model & Parameter estimate & Prob $>$ F & $\begin{array}{c}\text { Species } \\
\text { (number of observations) }\end{array}$ & MSE & $\mathrm{R}^{2} \mathrm{adj}$ \\
\hline $\mathrm{Y}=\mathrm{a}_{0}+\mathrm{a}_{1} \mathrm{ih}+\mathrm{a}_{2} \mathrm{CI}$ & $\begin{array}{l}\mathrm{a}_{0}=-0.34093942 \\
\mathrm{a}_{1}=3.45335517 \\
\mathrm{a}_{2}=0.44478752\end{array}$ & $\begin{array}{l}0.34417863 \\
1.12037697 \\
0.15949043\end{array}$ & $\begin{array}{l}\text { Norway spruce } \\
\quad(n=57)\end{array}$ & 0.51 & 0.33 \\
\hline $\mathrm{Y}=\mathrm{a}_{0}+\mathrm{a}_{1} \mathrm{ih}+\mathrm{a}_{2} \mathrm{CI}$ & $\begin{array}{l}\mathrm{a}_{0}=-0.17974109 \\
\mathrm{a}_{1}=2.20181378 \\
\mathrm{a}_{2}=0.50926120\end{array}$ & $\begin{array}{l}0.17376098 \\
0.43111043 \\
0.11000298\end{array}$ & $\begin{array}{l}\text { Silver fir } \\
(n=43)\end{array}$ & 0.69 & 0.65 \\
\hline
\end{tabular}
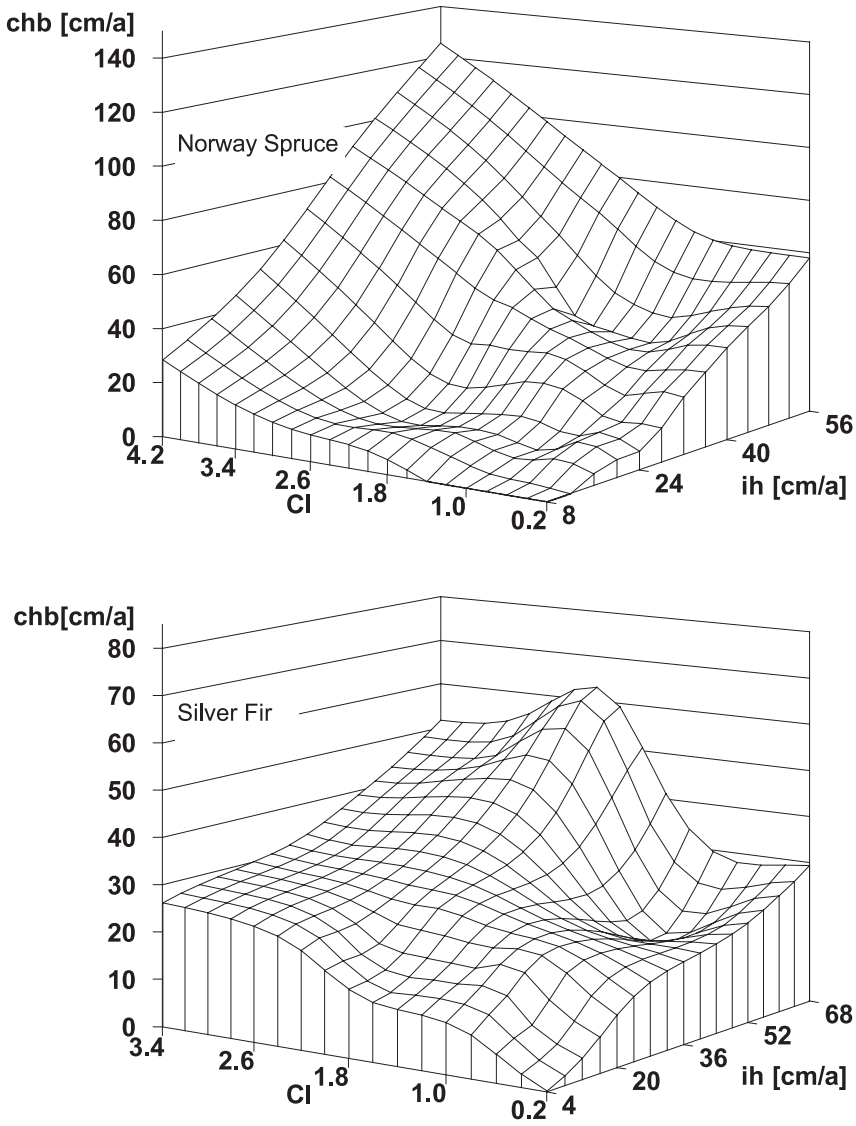

Figure 11. Change of the height to crown base (chb) as a function of competition (CI) and height increment (ih), for Norway spruce and Silver fir. (Three-dimensional response surface: the individual measurements were interpolated by a bivariate spline.)

Crown length and the variables which influence its variation are correlated with tree stability and tree survival. The response of crown length to competition can be utilised to improve growth models on an individual tree basis [35]. Most of the growth models which incorporate crown length variables were established in the Western US with conifer species [3, 6, 7, 23, 35, 36, 41, 43]. In Europe recently Pretzsch [27] and Hasenauer [14] have established growth prediction models with crown parameters as predictor variables.
The selected sample method to establish crown recession rate is an alternative to measurements in permanent observation plots. The principles of the applied branch dating technique has been proven in only a few studies before. Koehler [18], Andrews and Gills [1] and Rapraeger [28] opted for this technique when conducting studies in wood pathology. Recent focus on crown dimensions in relation with forest modelling led to a reversion to this method [21-23]. Furthermore, investigations on wood technology have used this approach, e.g. the analysis of branch development in Norway spruce stands of wide spacing [29]. In physiological studies, Fujimori [9] reconstructed the tree crown of Chamaecyparis obtusa in Japan by using the previously described technique.

The sample design used in this study led to acceptable accuracy of crown length estimation, compared with the sampling of all branch whorls in the dead branch zone of a tree. The sampling design also allowed the combination of classical stem analysis with the conduction of branch whorl analysis (see Sect. methods) and thus reduces the expense for data sampling. Maguire and Hann [22] developed sampling schemes for Douglas-fir in the Northwest of the US, where they sampled only four or two whorls per tree. Concerning the preparation technique of the branch whorl it turned out that with radial cuts the course of the tree rings and anatomical features which are used to determine branch mortality are more clearly visible. The zone where the dead branches have contact with the wood of the trunk was characterised as barrier zone, according to the Codit concept of Shigo [34]. In some cases of the present analysis the branches showed very small to nearly invisible rings shortly before dying, as it was found by Schöpf [31] in a study of natural pruning of Scots pine. Altogether, the branch dating technique for reconstructing past crown reveals some sources of bias:

(1) difficulty in determining height to crown base (i.g. discontinuous green branch zone).

(2) difficulty in exact estimation of the date of branch death due to very small or missing branch rings or due to insufficient sample preparation.

(3) the process of branch dying can last more than a year.

For this reason the arithmetic mean of the death dates of all branches was calculated in order to obtain the past status of crown base of a branch whorl.

An interesting result was that thinned Norway spruces also showed a slight decline in crown ratio. This negative tendency in regards to crown development is possibly due to (1) the shading effect of the neighbouring trees which remained, (2) the 
self-shading of the trees, especially of those with low crown transparency, both in combination with a lower shade-tolerance of Norway spruce, in comparison with Silver fir.

The application of the previously described technique revealed that crown recession oscillated from $16.2 \mathrm{~cm}$ to $56.8 \mathrm{~cm}$ per year (which is from $0.81 \mathrm{~m}$ to $2.84 \mathrm{~m}$ in 5 years) in the case of Silver fir and from $14.2 \mathrm{~cm}$ to $45.8 \mathrm{~cm}$ per year (equivalent to $0.71 \mathrm{~m}$ to $2.29 \mathrm{~m}$ in 5 years) for Norway spruce. In their investigation on Douglas fir (Pseudotsuga menziesii (Mirb.) Franco) in Oregon (300 to $1500 \mathrm{~m}$ of altitude) Maguire and Hann [23] found a mean annual change of the height to crown base of 3.8 feet (which is equivalent to $1.18 \mathrm{~m}$ ). Moreover, they adjusted a non-linear regression procedure to their crown recession data base, with height increment and competition as predictor variables.

In the present article, competition has a different impact on crown recession rate of the two species studied. Under the assumption that the adaptation of needles to the light conditions in the stands and the environmental conditions (water and nutrient supply) are similar, the different recession rates of the studied species are probably due to differences in shade tolerance (see Fig. 11). With increasing competition (decreasing light intensity) Norway spruce reduces its photosynthetic efficiency more rapidly than Silver fir and thus accelerates its natural pruning. The differences in crown length of Pinus contorta and Abies lasiocarpa in the US was explained by different shade tolerance [17].

The influence of growing space on crown dimension has been studied by Kramer [20] with even-aged Norway spruce stands. It was shown that crown ratio decreased from 95 to $35 \%$ from a stand age of 15 to 45 years. These findings proved the susceptibility of crown length to competition in young stands (from the juvenile to the pole stage). Short and Burkhart [35] and Hynynen [16] investigated the impact of thinning on crown ratio and established correction factors for the prediction models. Crown length can also be seen as a sort of memory of a conifer tree's competition history. Garcia [10] was able to quantify growth in a statespace model, with crown length as the state variable and climate and competition as further independent variables.

\section{CONCLUSIONS}

The above described technique to date branch mortality (together with the described design of branch whorl analysis) is technically and economically feasible and accurate enough to measure crown recession rate of Norway spruce and Silver fir. In order to determine current crown recession sampling variant 1 is preferable. If the intention is to estimate crown recession of the last 20 years sampling variant 2 should be applied.

Crown recession rate of the analysed trees depends significantly on height increment and competition status. The relationship between height increment and crown recession rate can be seen as an indicator of current competition (standing space). Crown recession analysis and its influencing factors reveal differences in shade tolerance between Norway spruce and Silver fir. Consequently Norway spruce should be thinned heavier in order to maintain the same crown ratio and thus photosynthetic capacity in comparison to Silver fir.

Acknowledgements: To Prof. Dr. H. Spiecker, Institute of Forest Growth, University of Freiburg for helpful comments and to Andrew Haywood, Institute of Forest Growth, University of Freiburg, for revising the language.

\section{REFERENCES}

[1] Andrews R., Gills S., Determing the time branches on living trees have been dead, J. For. 37 (1939) 930-935.

[2] Assmann E., Principles of forest yield study, Pergamon Press, New York, 1970.

[3] Biging G., Wensel L., Modelling Mixed Species, Multiple Aged Conifer Forests in California, Proceedings of IUFRO Centennial Meeting Berlin/Eberswalde (1992) 163-170.

[4] Burger H., Holz, Blattmenge und Zuwachs (Eds.), Mitt. EAFV. Band 21: Kronenaufbau gleichaltriger Nadelholzbestände (19371953) 5-58.

[5] Cole W.G., Jensen C.E., Models for describing vertical crown development of lodgepole pine stands, USDA For. Serv. Res. Pap. INT-292, 1982.

[6] Dyer M.E., Burkhart H.E., Compatible crown ratio and crown height models, Can. J. For. Res. 17 (1987) 572-574.

[7] Ek A.R., Monserud R.A., Trials with program FOREST - Growth and reproduction simulation for mixed species even- or unevenaged forest stands. In: J. Fries (Ed.): Growth models for tree and stand simulation, Royal College of Forestry, Research Notes No. 30 (1974) 56-76.

[8] Forstliche Bundesversuchsanstalt, Instruktionen für die Feldarbeit der Österreichischen Forstinventur, Forstliche Bundesversuchsanstalt Wien, 1994.

[9] Fujimori T., Dynamics of crown structure and stem growth based on knot analysis of a hinoki cypress, For. Ecol. Manage. 56 (1993) $57-68$.

[10] Garcia, O., The state-space approach in growth modelling, Can. J. For. Res. 24 (1994) 1894-1903.

[11] Gerecke K.-L., Zuwachsuntersuchungen an vorherrschenden Tannen aus Baden- Württemberg, Allgemeine Forst-und Jagdzeitung 157 (1986) 59-68.

[12] Hamilton G.J., The dependence of volume increment of individual trees on dominance, crown dimensions and competition, Forestry 42 (1969) 133-144.

[13] Hann D.W., Walters D.K., Scrivani J.A., Incorporating crown ratio into prediction equations for Douglas-fir stem volume, Can. J. For. Res. 17 (1987) 17-22.

[14] Hasenauer H., Zur Modellierung der Kronenlängenveränderung in verschieden dichten Fichtenbeständen, Allgemeine Forst-und Jagdzeitung 165 (1993) 88-93.

[15] Hegyi F., A simulation model for managing jack pine stands, in: Growth models for tree and stand simulation, J. Fries (Ed.), Royal College of Forestry, Stockholm, 1974, pp. 74-90.

[16] Hynynen J., Predicting tree crown ratio for unthinned and thinned Scots pine stands, Can. J. For. Res. 25 (1995) 57-62.

[17] Jack S.B., Long J.N., Analysis of stand density effects on canopy structure, a conceptual approach, Trees 5 (1991) 44-49.

[18] Koehler A., A method to study knot formation, J. For. 34 (1936) 1062-1063.

[19] Kramer H., Dong P.H., Kronenanalyse für Zuwachsuntersuchungen in immissionsgeschädigten Nadelholzbeständen, Forst und Holz 40 (1985) 115-118.

[20] Kramer H., Kronenaufbau und Kronenentwicklung gleichalter Fichtenpflanzbestände, Allgemeine Forst-und Jagdzeitung 133 (1962) 249-256. 
[21] Maguire D.A., Hann D.W., A stem dissection technique for dating branch mortality and reconstructing past crown recession, For. Sci. 33 (1987) 858-871.

[22] Maguire D.A., Hann D.W., A Sampling Strategy for Estimating Past Crown Recession on Temporary Growth Plots, For. Sci. 36 (1990) 549-563.

[23] Maguire D.A., Hann D.W., Constructing models for direct prediction of 5-year crown recession in south-western Oregon Douglas-fir, Can. J. For. Res. 20 (1990) 1044-1052.

[24] Mitchell K.J., Dynamics of simulated yield of Douglas-fir. For. Sci. Monogr. 17 (1975) p. 39

[25] Mitscherlich G., Der Tannen-Fichten-(Buchen)-Plenterwald, Schriftenreihe der Badischen, Forstlichen Versuchsanstalt 8, 1952.

[26] Monserud R.A., Sterba H., A basal area increment model for individual trees growing in even- and uneven-aged forest stands in Austria, For. Ecol. Manage. 80 (1996) 57-80.

[27] Pretzsch H., Konzeption und Konstruktion von Wuchsmodellen für Rein- und Mischbestände, Schriftenr. d. Forstl. Fak. München und d. Bay. Landesanstalt f. Wald und Forstw. 115, 1992.

[28] Rapraeger E.F., Development of branches and knots in western white pine, J. For. 37 (1939) 239-245.

[29] Sauter U.H., Fahrbach M., Ästigkeitsverhältnisse und Schnittholzqualität in einem weitständig begründeten Fichtenbestand, Allg. Forst Z. 48 (1993) 875-878.

[30] Schmid-Haas P., Masumy S.A., Niederer M., Schweingruber F.H., Zuwachs- und Kronenanalysen an geschwächten Tannen, Schweiz. Z. Forstwes. 137 (1986) 811-832.

[31] Schöpf J., Untersuchungen über Astbildung und Astreinigung der Selber Kiefer, Fowi.Cbl. 73 (1954) 275-290.

[32] Schöpfer W., Zusammenhang zwischen Wuchsraum und Zuwachs in erkrankten Fichten- und Tannen-Beständen, Forst und Holz 41 (1986) 315-319.

[33] Schütz J.-Ph., Grundner K., Mandallaz D., Die Vitalität von Weißtannen und ihre Abhängigkeit von bestandesstrukturellen, ertragskundlichen, ernährungskundlichen und waldbaulichen Variablen, Fowi.Cbl. 105 (1986) 406-420.

[34] Shigo A.L., Tree decay: An expanded concept, USDA For. Serv. Agric. Inf. Bull. No. 419, 1979.

[35] Short E., Burkhart H., Predicting crown height increment for thinned and unthinned loblolly pine plantations, For. Sci. 38 (1992) 594-610.

[36] Smith W.R., An empirical evaluation of a three-dimensional crown model for predicting volume growth, For. Ecol. Manage. 69 (1994) 199-209.

[37] Spathelf P., Orientierungshilfe zur Prognose und Steuerung des Wachstums von Fichten (Picea abies (L.) Karst.) und Tannen (Abies alba Mill.) in Überführungswäldern mit Hilfe der relativen Kronenlänge, Schriftenreihe Freiburger Forstliche Forschung, Band 4, 1999.

[38] Spiecker H., Zusammenhänge zwischen sozialer Stellung, Kronenlänge, Kronenschluß und der Gesundheit von Weißtannen, AFZ 38 (1983) 442-443.

[39] Spiecker H., Das Wachstum der Tannen und Fichten auf Plenterwald-Versuchsflächen des Schwarzwaldes in der Zeit von 1950-1984, Allgemeine Forst-und Jagdzeitung 157 (1986) 152-164.

[40] Spiecker H., Zur Steuerung des Dickenwachstums und der Astreinigung von Trauben- und Stieleichen (Quercus petraea (Matt.) Liebl. und Quercus robur L.), Schriftenr. d. Landesforstverwaltung Ba.-Württ. 72, 1991.

[41] Valentine H.T., Ludlow A.R., Furnival G.M., Modeling crown rise in even-aged stands of Sitka spruce or loblolly pine, For. Ecol. Manage. 69 (1994) 189-197.

[42] Van Laar A., Influence of tree parameters and stand density on diameter growth of Pinus radiata, S. Afr. For. J. 70 (1969) 5-14.

[43] Ward W.W., Live crown ratio and stand density in young evenaged red-oak stands, For. Sci. 10 (1964) 56-65.

[44] Weck J., Über die Eignung von Kronenmeßwerten als Weiser für die Zuwachspotenz von Bäumen und Beständen im Wirtschaftswald, Allg. Forst Z. 6 (1951) 469-473. 